\title{
Ultra-Deep Drilling through 3.5-Billion-Year-Old Crust in South Africa
}

by Maarten de Wit

\section{Introduction}

The Makhonjwa Mountains of South Africa and Swaziland comprise some of the most sought-after geo-real estate in the world. It is priceless-that is, for geoscientists-because the rocks of this approximately $120 \mathrm{~km}$ by $60 \mathrm{~km}$ corner of southern Africa, also known as the Barberton Greenstone Belt, date back to 3.2-3.6 billion years (Ga), representative of Earth in early Archean times when it was still $\sim$ Ga years young. They are not the very oldest rocks on Earth (those occur in Greenland and Canada), but they are the oldest best-preserved ones; thus, this stretch of land is without equal for research into the early history of our Earth. It is home to some of the earliest fragments of island arc, oceanic crust, and vestigial tracts of continent covered with sedimentary and volcanic rocks. So well-preserved are these rocks that unless one radiometrically dates them, it is near impossible to distinguish them from many modern rocks. This exceptional preservation has ensured that the

\begin{tabular}{|c|c|}
\hline Name & Affiliation \\
\hline L Ameglio & Exige, Geophysical Services, RSA \\
\hline R Armstrong & Australian National University, Australia \\
\hline N Arndt & University of Grenoble, France \\
\hline N Banerjee & University of Western Ontario, Canada \\
\hline A Biggin & University of Liverpool, UK \\
\hline M de Wit & AEON, University of Cape Town, RSA \\
\hline T Dhansay & student, AEON and Council of Geoscience, RSA \\
\hline M Doucouré & AEON, University of Cape Town, RSA \\
\hline J Ebbing & Geological Survey of Norway, Norway \\
\hline J Erzinger & $\begin{array}{l}\text { GFZ German Research Centre for Geosciences, } \\
\text { Potsdam, Germany }\end{array}$ \\
\hline C Fourie & TUT, Tshwane University of Techology, RSA \\
\hline D Frei & Geol Survey of Denmark, Denmark \\
\hline C Jaupart & $\begin{array}{l}\text { IPGP, Institute de Physique du Globe, Paris, } \\
\text { France }\end{array}$ \\
\hline C Langereis & University of Utrecht, Holland \\
\hline S MacLennan & student, AEON, University of Cape Town, RSA \\
\hline M Mesli & Geological Survey of Norway, Norway \\
\hline C Rice & Drilling Technology SA, RSA \\
\hline O Ritter & $\begin{array}{l}\text { GFZ German Research Centre for Geosciences, } \\
\text { Potsdam, Germany }\end{array}$ \\
\hline P Robinson & $\begin{array}{l}\text { Dept Earth Sciences, Dalhousie University, } \\
\text { Canada }\end{array}$ \\
\hline G Stevens & $\begin{array}{l}\text { Stellenbosch University, Dept Earth Science, } \\
\text { RSA }\end{array}$ \\
\hline A van Wyk & Drillers in Training CC, RSA \\
\hline U Weckman & $\begin{array}{l}\text { GFZ German Research Centre for Geosciences, } \\
\text { Potsdam, Germany }\end{array}$ \\
\hline A Wilson & University of Witwatersrand, RSA \\
\hline
\end{tabular}

Makhonjwa rocks yield the oldest directly dated and undisputed signs of life on Earth, and compared to our present biosphere they also provide detailed clues about the hostile nature of the paleoenvironments under which this life struggled to persist. One severe challenge entailed coping with more potent solar radiation to which life is particularly sensitive, when Earth's magnetic field was too weak to efficiently shield the surface from the relentless solar wind of lethal charged particles. Another is to explore for paleo-suture zones that can help establish when plate tectonics first emerged as the dominant solid earth recycling process to nurture the only sustainable habitable zone in our solar system. These then represent some of the targets of a new deep drilling project, on which an ICDP workshop was focused and held on 13-19 April 2010.

The workshop was attended by two students and twenty-one international scientists from four continents (Table 1), each with a different expertise and perspective with which to contemplate an $8-10 \mathrm{~km}$ drillhole through this unique terrain, as part of building an Early Earth Conservatory. The workshop was held at Travelport, the 'Cradle of Life' Conference-Conservation center, some $15 \mathrm{~km}$ from the town of Emanzana (formerly Badplaas), South Africa. The site is within walking distance from the world's oldest identified suture zone, the prime drilling target for this project (Fig. 1).

The project is both scientific and applied in scope. It is meant to characterize Earth's oldest subduction/suture zone and its paleoenvironments, to study the deep ancient and modern biosphere in pristine Archean crust, to establish a permanent 'on-site' early Earth laboratory-museum-educatorium in rural Africa, and to link these facilities to an African college of drilling technology.

\section{Scientific Background}

\section{Tectonics}

The existence and especially the onset of early Archean $(>3.0 \mathrm{Ga})$ present-day style plate tectonics remains controversial, despite many studies having addressed this topic. Alternative models include plume dominated processes and crustal delamination during which vertical motions controlled Archean tectonics (Van Kranendonk, 2007; Hamilton, 


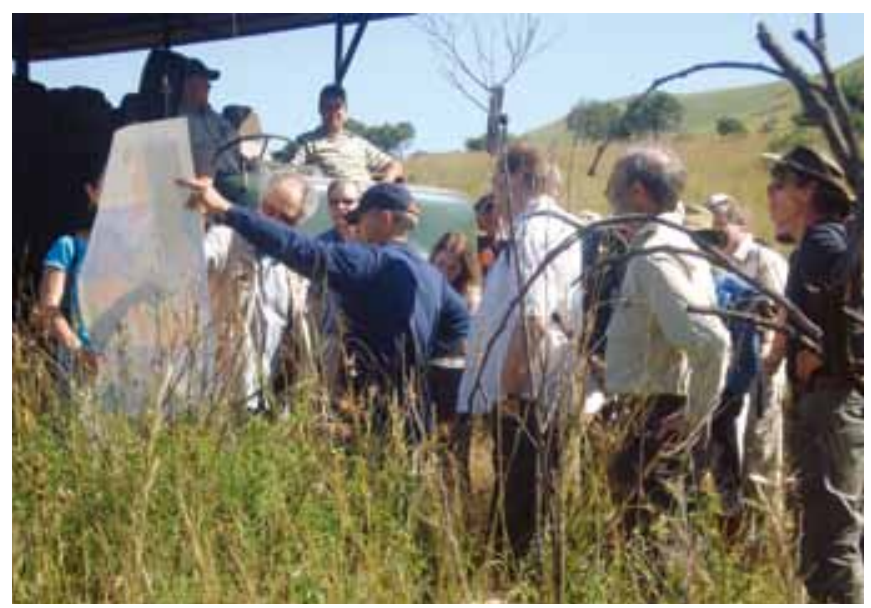

Figure 1. Workshop participants in the field at a potential drill area.

2007). This controversy on the nature of Archean tectonics has been extensively debated over the last two decades without reaching consensus. Recent field-based research has provided some evidence for plate tectonics as early as $3.1 \mathrm{Ga}$ and possibly as early as $3.8 \mathrm{Ga}$, but this is not generally accepted as conclusive (Schoene and Bowring, 2010; de Wit et al., 2011; Furnes et al., 2009). Geochemical analysis of Archean rocks shows that between $3.5 \mathrm{Ga}$ and $3.8 \mathrm{Ga}$, Archean crust formation can, with apparent equal validity, be interpreted to have been generated during mantle plume magmatism or through subduction processes similar to that associated with plate tectonics (Bédard, 2006). Numerical modeling based on high mantle temperatures and geotherms, as is generally assumed for the Archean, is consistent with whole mantle plume tectonics (Davies, 2007). Similar modeling, particularly with a hydrous mantle, shows that plate tectonics is also capable of removing the required excess heat produced in the Archean at a rate of operation comparable to, and possibly even lower than, its current rate (Grove and Parman, 2004). In any case, recent thermochronology and petrology have questioned the existence of ubiquitous higher geothermal gradients everywhere during the Archean (Moyen et al., 2006; Diener et al., 2005).

A fundamental difference between plate tectonics and other scenarios is the occurrence of large horizontal lithosphere motion. Geological observations have revealed early Archean horizontal crustal motion. Extension and forma tion of sedimentary basins as early as $3.49 \mathrm{Ga}$ and $3.45 \mathrm{Ga}$, as well as significant horizontal shortening episodes between 3.4 Ga and 3.2 Ga, suggest significant horizontal tectonic processes that possibly, but not definitively, reflect plate tectonic motions. The shortening episodes include associated high-pressure, low-temperature metamorphism in the Barberton Greenstone Belt at 3.2 Ga. Attempts at establishing extents and rates of horizontal motions of Archean terrains using paleomagnetism, have been suc-cessful only in terranes younger than 3.0 Ga (Strik et al., 2003; de Kock et al., 2009). Thus, a unified tectonic model for the early Archean Earth remains elusive. The interpretations and models remain controversial largely because of lack of geo- physical data and robust structural/paleomagnetic analyses of tectonic events without precise thermochronology and pristine borehole samples.

\section{Early life and ancient life-support systems}

It has long been argued that understanding Archean tectonic processes provides fundamental keys to unraveling the origin and formation of Earth's earliest continents (cratons), its paleoenvironments, early ecosystems, and life.

Several decades have passed since the first description of recognizable early Archean microfossils (de Wit, 2010), yet morphology-focused imaging techniques of fossil-like objects and stable isotope $(\mathrm{C}, \mathrm{N}, \mathrm{S})$ compositions of putative organisms have repeatedly failed to pose limits on the interpretation of the biogenic origin of the microstructures. Additionally, several abiologic metamorphic and hydrothermal reactions have been identified that can produce kerogen and graphite, and specific abiologic processes have been described that can generate complex structures that resemble microfossils (McLoughlin et al., 2007). In view of these uncertainties and controversies, it is clear that elucidating how and when life may have originated on Earth requires first to understand the conditions that prevailed early in Earth's history and the environments in which life may have appeared and later evolved. The recent discovery (Furnes et al., 2004) and in situ dating of ichnofossils in the rims of the world's oldest pillow lavas in Barberton (Fliegel et al., 2010) has dramatically shown that rocks previously ignored in studies of early life (e.g., basaltic igneous rocks) now offer a new paleoenvironment as habitats for early life. This holds great potential to track life back even further in time and must be considered a promising focus for such early life studies in places like the Barberton Greenstone Belt.

\section{What the Makhonjwa Mountains can offer Archean science}

The lower rock sequences of the Barberton Greenstone Belt and its surrounding granitoid terranes comprise the best well-preserved Paleo-Archean section of continental crust in the world (Fig. 2). The area contains rocks that have never been deeply buried, except within a limited zone in the southwest part of the belt where high-pressure, low-temperature metamorphism at $3.2 \mathrm{Ga}$ has been recorded. This zone-part of the Inyoka fault system-has recently been suggested to represent a 3.2-Ga suture zone, separating two low-grade continental arc/back-arc/oceanic terranes of slightly different ages and geological history (Moyen et al., 2006). A similar second zone has been identified on the basis of thermochronology and structural mapping (Schoene et al., 2008, 2009) flanking the southeast margin of the belt, separating the central Barberton belt from a continental arc terrane, the Ancient Gneiss Complex. This implies that the two oldest sutures of the world are present in this area. Recent paleomagnetic studies on these older 
sequences of the Barberton terranes provide intriguing preliminary evidence that a stable and reversing geomagnetic field was up and running at $\sim 3.5 \mathrm{Ga}$, and that horizontal motions were on the order of $\sim 12 \mathrm{~cm} \mathrm{yr}^{-1}$-fast by today's standards, but well within the range of plate velocities observed in the Phanerozoic (Biggin et al., 2011).

\section{Key scientific questions analyzed during the workshop}

- Did plate tectonics operate 3.5 billion years ago?

- What is the geophysical character/image of the world's oldest suture zones?

- Do the proposed suture zones of the Barberton Greenstone Belt, which separate at least three different terranes, penetrate the entire crust, and how do they affect the old underlying lithospheric mantle?

- Are paleomagnetic reconstruction of plate motions fast or slow, and are we dealing with large or small plates?

- What was the intensity of earliest geomagnetic field in relation to inner core growth?

- What is the nature/age of the crust beneath the oldest preserved terranes?

- How did the earliest continental fragments of the Kaapvaal craton form and amalgamate to create Earth's first stable continent? What was its geothermal gradient?

- Are we dealing with a 'hot/dry' mantle or a 'wet/cool' Archean mantle? What were the geothermal gradients within different Archean terranes?

- How did early suture zone tectonics and related thermo-chemical fluid processes, including serpentinization, influence early life and ecosystems and gold metallogenesis?

- What is the depth distribution and biochemistry of extremophiles in the deep biosphere of the Archean compared to that of today in the same rock sequences?

- What was the optimum temperature window for preservation of microfossils in different Archean terranes?

- Can we define chemical fingerprints of interactions between fluids, rocks and microbes?

- Were Archean ocean/atmosphere temperature and composition hot or cold?

- Is the atmosphere redox state reduced or oxidized, or episodically both?

- Can microbial contamination be defined and quantified?

\section{What the Makhonjwa Mountains can offer rural development in Africa}

The Barberton Greenstone Belt is a geological hotspot that is presently being considered as a UNESCO world heritage site. The region has been a 'mecca' for countless generations of Earth and life scientists and has been a key location where significant new scientific ideas have emerged. This remains so to this very day, with new research programs and at least three shallow scientific drilling projects having been completed recently and/or planned for completion soon. The Barberton Greenstone Belt is a well-known region for teaching of field geology and studies in early Earth processes to undergraduates and research students from South Africa and other countries. Tourist routes are now also starting to include the region, but few local people benefit from its rich history. The area under investigation is rural and poor, without adequate schooling and health facilities in crowded townships. Education opportunities for young people are scarce and uninspiring. Field schools and excursions (national and international) are frequent, but few if any engage with local youth. The plans for a deep drill site will be dovetailed with outreach and education requirements of the local, rural communities. Several scientists at the workshop cooperate closely with local nature reserves (Songimvelo and Nkomazi), the Mpumalanga Parks Board, and local tourist agencies. In addition, in-depth discussions have been held with local farmers and entrepreneurs, traditional leaders, and regional and national government representatives about the vision of linking a deep drilling site to a local center for early Earth studies attractive to schoolteachers, schoollearners, undergraduate students, and research scientists alike. These discussions have been welcomed by all these stakeholders.

\section{Key socioeconomic \& education questions addressed during the workshop}

- How can we develop a long-lasting scientific interest in the early Earth that will also benefit the local rural communities, and in particular develop science and engineering skills related to geo-technology in rural Africa?

- How can we best dovetail scientific research with science and environmental outreach programs for general public awareness and youth education?

- Can we develop a local training center for drilling and related mining technology?

- Can we develop a rural center for early Earth studies, with open access for all researchers and learners to relevant materials and literature?

\section{Workshop summary}

Talks were presented on the regional geology and geophysics of the Barberton Greenstone Belt and surrounding regions, together with detailed overviews about the petrology and thermodynamics of the rocks found within and flanking the Inyoka Shear Zone (ISZ). These data form the backbone for models that represent the ISZ as a $3.2-3.3 \mathrm{Ga}$ paleo-suture zone, within which evidence is preserved for a low Archean geothermal gradient of $10^{\circ} \mathrm{C}-20^{\circ} \mathrm{C} \mathrm{km}^{-1}$ that was subsequently overprinted by higher temperatures at lower pressures, indicative of collision and exhumation tec- 
tonics. This is contrary to conventional theories that all Archean environments had high geotherms (Hamilton, 2007). The drilling through the ISZ is thus a prime target for the study of a range of early Earth processes in an environment similar to those in modern subduction and suture zones. Geologically, the ISZ coincides with a number of highly deformed serpentinized peridotites and tectono-sedimentary melange rocks similar to those found along Phanerozoic suture zones and active plate boundary faults such as the Alpine Fault in New Zealand. Midway through the workshop, participants visited a potential drill site near the surface exposure of the ISZ (Fig. 1) flanked on one side by serpentinites and on the other by a sequence of sandstones and conglomerates, not unlike that found at the San Andreas Fault Observatory at Depth across the San Andreas Fault.

Overviews of the geophysics and a preliminary 3-D model of the greenstone belt indicates that a $10-\mathrm{km}$-deep drillhole also has the potential to pierce the base of the belt and thus allow a detailed examination of the contact with the underlying rocks of the middle Archean crust. These contacts are invariably interpreted as deep tectonic boundaries that have been explicitly implicated (de Wit and Ashwal, 1997) as incubators for epi-mesothermal gold deposits, hallmarks of greenstone belts throughout the world. In view of the relatively poor surface outcrop, a complete section (assuming high core recovery) will allow systematic changes to be recorded through the com-
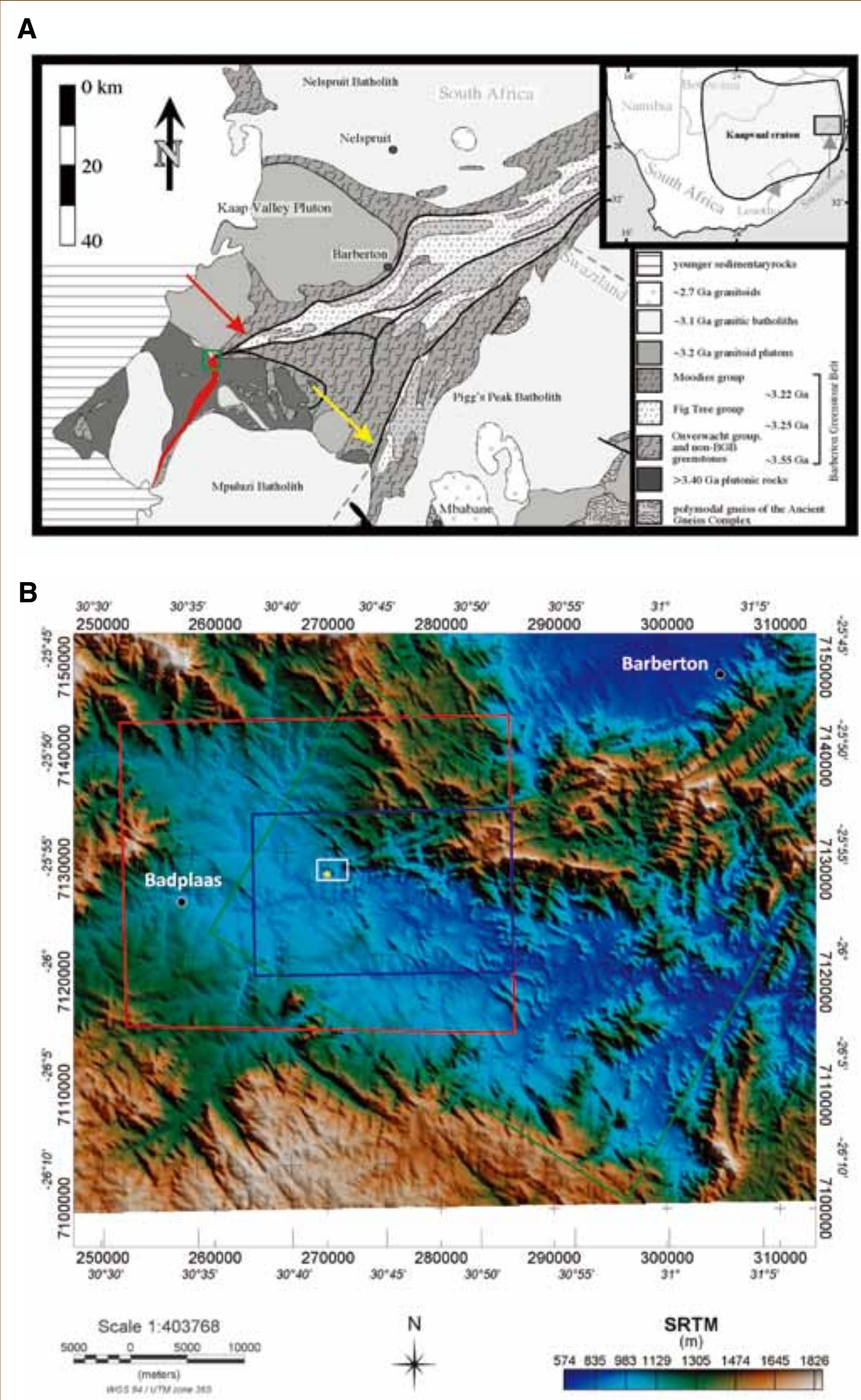

Figure 2. $[A]$ Archean tectono-stratigraphic map of the Barberton Greenstone Belt as part of the Archean Kaapvaal craton (inset upper right). Three major tectonic terranes that comprise the Barberton region are separated by major tectonic boundaries (black solid lines), two of which (the Inyoka and Manhaar shear systems, indicated by red and yellow arrows, respectively) may represent $\sim 3.2$-Ga suture zones. Also shown in thick red is the inferred continuation of the Inyoka shear system within the granitoid terrain to the southwest of the greenstone belt, and the potential area for a deep drill site (green box). [B] SRTM image of the southern part of the greenstone belt, showing the area of ongoing high-resolution aeromagnetic surveying (dark blue box), and the potential deep drill site area (pale blue box). Also shown are the locations of Badplaas and Barberton. Note the undeformed NW-SE dykes swarm (positive topography) that cut the area that have been dated at $2990 \mathrm{Ma}$ 
plex rock sequences with tectonic zones, and small features that are likely to be hidden in even the best outcrops will be much easier to interpret. Measurements on detailed chemical and physical parameters of the core are needed to ground truth geophysical profiles. Misapplication of seismic models developed for sedimentary sequences to metamorphic basement in the German Continental Deep Drilling Project, for example, resulted in erroneous interpretations (Emmermann and Lauterjung, 1997).

Workshop talks were presented also on how to collect fluids and gases, past and present, at all levels through a drilled sequence of this nature, and to measure changes in these over time and depth. The most abundant volatiles in common crustal rocks are water and carbon dioxide. However, little is known about the distribution and behavior of hydrocarbons, hydrogen, nitrogen, and noble gases in ancient continental crust. Generally these elements are minor components in crystalline rocks and, hence, do not significantly influence the physical or thermodynamic properties of a rock, but they have a large potential in tracing mass and heat transport processes. Moreover, noble gases $\left({ }^{4} \mathrm{He},{ }^{40} \mathrm{Ar}\right)$ and $\mathrm{N}$ in natural gases, crustal fluids, and fluid inclusions can be used as indicators of the fluid sources, and they are thus helpful in trying to solve questions of fluid generation, flow, and evolution in the deep crust.

These talks were complemented by biogeochemical views of how such a deep laboratory can further probe the present and past deep biosphere (microbiota) in rocks that may have harbored life as long ago as $3.4 \mathrm{Ga}$. The paleomagnetists also emphasized the need for careful magnetic measurements to constrain magnetic field strength variability, and the heat-flow modelers recommended in situ measurements of heat flow, conductivities, heat-producing elements, and high-resolution thermochronology to constrain variations in paleogeotherms.

The value and pitfalls of different types of geophysical surveys prior and during deep drilling projects, including the German KTB borehole, were presented and deliberated extensively during the workshop. In addition, an overview of the technical drilling capacity and training in South Africa was given by professional drilling consultants to the African mining industry. In 2009 the Mining Qualifications Authority estimated that there was a shortage of some 1200 drillers in South Africa, and the requirement for a steady stream of trained drillers into the broader African drilling industry will always be large. South African mining houses have for many years drilled some of the deepest cored boreholes in the world. In 2010 approximately fourteen boreholes were being drilled to depths in excess of $3500 \mathrm{~m}$, but all of this drilling is still done using drilling systems that were developed many years ago. The need for an innovative approach to deep level core drilling is very great indeed.
The workshop also included an open 'town hall' meeting for the public, land owners, local school teachers and learners, non-governmental organization (NGO) representatives, and the media. Clearly, the workshop was a success judging not only by the interest in this project from a curiosity driven perspective, but also from the perspective of developing new drilling technology and the dire need for a sustainable education/training facility to ensure drilling expertise from Africa. It was perhaps surprising to learn that despite a severe shortage of drilling expertise and the great number of ongoing drilling projects in the exploration and extraction industries throughout onshore and off-shore Africa, there is nowhere in Africa for young people to pursue a career in drilling other than on-site learning on the job. The establishment of a training college focused on improving drilling (and possibly mining) skills would advance the goals of developing educational opportunities and drilling capabilities.

\section{Recommendations}

There was strong consensus at the workshop that we need to firmly establish whether more can be learned from two $5-\mathrm{km}$ holes or several shallower holes, instead of one $10-\mathrm{km}$ hole. Before further deliberations on this, and before honing in on a potential area, let alone a precise drill-site, there was unanimous agreement that a number of detailed surveys need to be completed. For example, more detailed surface mapping of the ISZ is required, in particular through higher resolution structural mapping and analyses. However, because of limited exposure a number of geophysical surveys are also prerequisites before the project can move into a drill-planning stage.

While preliminary 3-D gravity and magnetic models of the Makhonjwa Mountains were presented, their present utility is severely hampered by the lack of sufficiently highresolution gravity, magnetic, and borehole data. Moreover, no crustal seismic reflection data are available. Although a teleseismic experiment has yielded a crustal thickness in this region of $\sim 43 \mathrm{~km}$ from converted P-S wave receiver-function analyses, this experiment failed to provide any significant insights into the internal crustal structures (Nguuri et al., 2001). Current aeromagnetic data is too coarse to resolve the geology of the area. Additional geophysical methods (magnetotelluric magnetic, seismic) are therefore required, and only high-resolution data will improve the reliability of 3-D models required to understand surface structures with depth.

Developing plans for on-site, real-time mud-gas analysis during drilling-similar to those developed during drilling of the German KTB borehole, and in numerous scientific drilling projects since then-was proposed as essential at an early stage. Hydrocarbons, helium, radon, and (with limitations) carbon dioxide and hydrogen are the most suitable gases for the detection of fluid-bearing horizons, shear zones, open fractures, and sections of enhanced permeabil- 
ity. These will provide critical samples and analyses of ephemeral gas/fluid pockets penetrated during drilling that might otherwise escape unnoticed, and will provide essential guidance for decisions related to later fluid sampling and in situ hydrologic testing. Subsequent off-site isotope studies on mud gas samples help reveal the origin and evolution of deep-seated crustal fluids. Studies of crustal scale fluid transport over large distances and times indicate that fluid transport rates are significantly in excess of predictions based on simple theory (Erzinger and Stober, 2005). This implies that fluid flow in the deep crust is mechanically enhanced and/or episodic. The specific rare gas components will indicate the relative proportions of fluids arising from meteoric, magmatic, metamorphic, and mantle sources. Information about the evolution of fluids in space and time should result from investigations of the chemical and isotopic fingerprints of rocks and minerals, which were influ- enced by fluid/rock interaction and fluid inclusions trapped as remnants of past fluids but also from the chemical-isotopic composition of fresh fluids present in open cavities and fractures. Therefore, such studies are fundamental to the success of a deep drilling project. Thus, while drilling campaigns provide unique opportunities to sample indigenous fluids/gases continuously from a section of the upper crust, site survery work needs to be completed prior to actual drilling.

As drill sites are selected, it is necessary to evaluate existing information on the local hydrology, hydrochemistry, and the occurrence of aquifers. A science team will plan to measure hydrologic properties at several levels by packing off favorable sections and to collect water samples (e.g., for tritium and noble gas isotope analyses [He, $\mathrm{Ne}, \mathrm{Ar}, \mathrm{Kr}$, and $\mathrm{Xe}$, stable isotope analyses [H, C, O, and S]), and for complete chemistry of dissolved constituents.
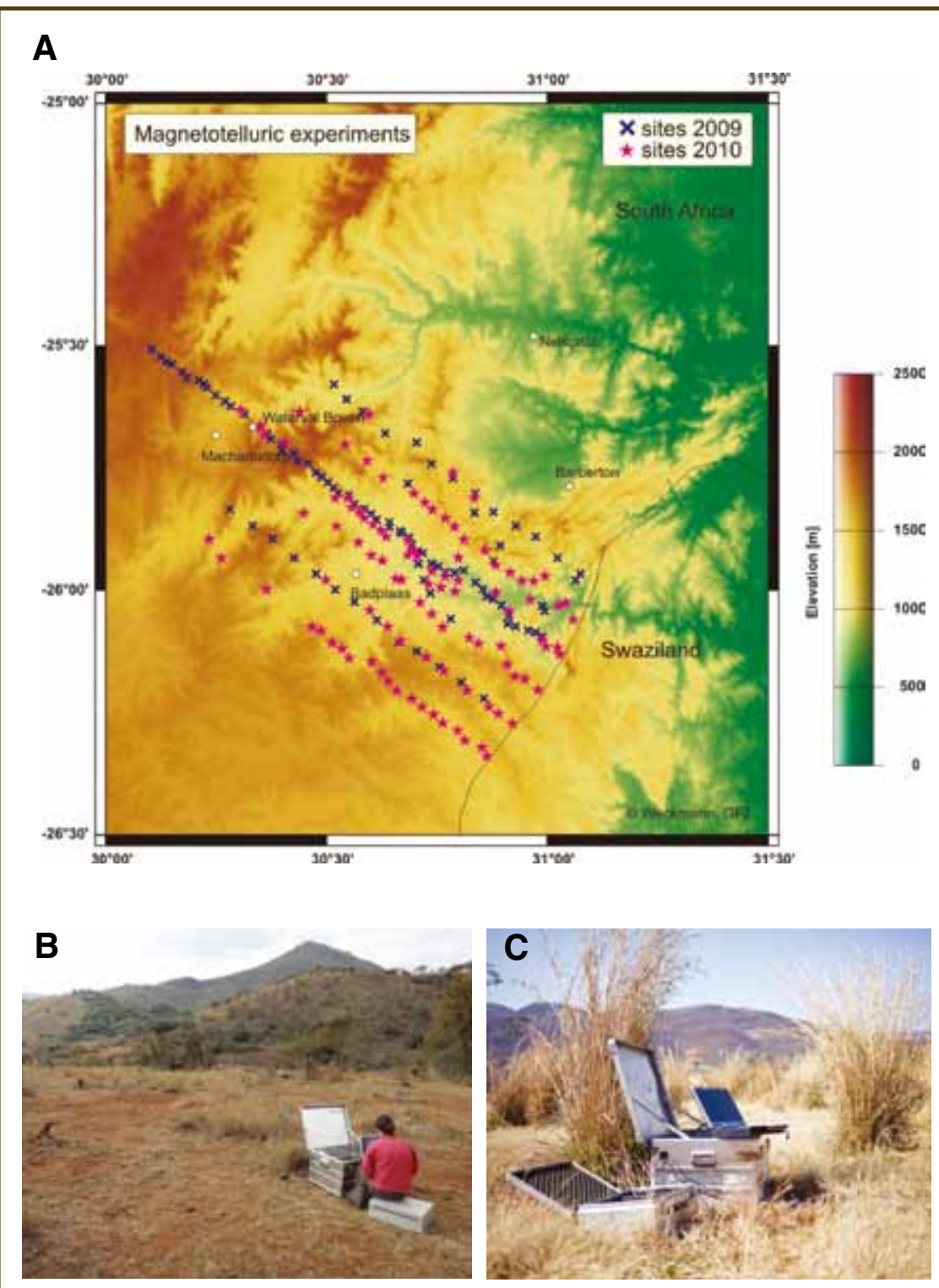

Figure 3A. [A] Layout of the high-resolution magnetotelluric (MT) survey across the Inyoka Shear Zone that runs approximately between Barberton and Badplaas. [B, C] Typical field setup of MT stations. Care was needed to ensure the equipment and cables were not damaged by wild animals, including rhinos and hippos.
Ensuring successful drilling deep into the oldest suture zone will require the early cooperative efforts of many nations and experts, and good coordination is essential. Prior to drilling, a long lead time is required to establish a precise location where the suture will occur at depth and how its local dip might vary. Besides detailed geophysics, it will be important to obtain additional information through a number of shallow reconnaissance pilot holes at relatively low cost. Both partial core recovery and downhole geophysical logging will provide crucial information to improve 3-D modeling.

\section{Ongoing Work}

As part of laying further foundations for this project, ongoing work has focused on a detailed magnetotelluric (MT) survey (Weckmann et al., 2009) across the Inyoka paleo-suture zone and surrounding rocks to obtain high-resolution images of the shear zones. Over two consecutive years (2009-2010), two large MT experiments were carried out. To gain good 3-D coverage, 5-component MT data were recorded in a frequency range from $0.001 \mathrm{~s}$ to $1000 \mathrm{~s}$ at almost 200 sites (at an average spacing of $\sim 2 \mathrm{~km}$ ) arranged along a 110-km-long transect and five shorter transects covering an area of $\sim 300 \mathrm{~km}^{2}$ (Fig. 3). This setup provides good areal coverage of the ISZ and also a vertical resolution on lithospheric scale. The main difficulties for electromagnetic experiments in the Barberton area are the various man-made noise sources (e.g., electric fences, power lines, mining 
activities and a major DC railway line). Hence, the natural electromagnetic field variations are overprinted by these strong electromagnetic signals. Nevertheless, the first 2-D inversion tests along the $110-\mathrm{km}$ transect with a reduced data set already show strong correlation with subsurface geology, and zones of high electrical conductivities appear to correlate well with the surface location of known faults. The results of the MT work is being further integrated with ongoing laboratory conductivity measurements on representative rock samples collected across the suture zone during detailed structural mapping of a well exposed part of the ISZ.

A high-resolution aeromagnetic and radiometric survey is planned for March 2011, using the low flying Gyrocopter Kreik IIB from GyroLAG (Gyrocopter Light Airborne Geophysics), to complement the MT work. A special feature of this light airborne geophysics platform, which requires no formal landing strip, is its capability of performing safely at survey heights as low as $5 \mathrm{~m}$ above ground level at relatively slow speeds (75-100 $\left.\mathrm{km} \mathrm{hr}^{-1}\right)$, resulting in a significant improvement in quality of data (equivalent of $2-3 \mathrm{~m}$ ground equivalent sampling intervals).

Plans to establish an Africa college for drilling technology are in progress with the Tswana University of Technology (TUT) and relevant government agencies. Local property owners have identified several suitable sites where such a rural extension of TUT might be built. As part of a new drilling technology development initiative, an early start on developing a new type of high-speed coring turbine drill bit has begun at TUT. Although the design has not been finalized, the proto-drill includes a fluid-powered and cooled rotating drill head with a stationary drillstring, and a mechanism for core to be brought up via a core-mouse inside the drilling stem. Also part of this initiative is design of new drill bits (based on recent developments in synthetic diamond manufacturing techniques), face discharge designs, and hybrid bit designs.

\section{Conclusion}

We are confident that the proposed geophysics transects in the Barberton area will yield high quality depth profiles down to Moho and possibly deeper. This will allow imaging of the proposed suture zones, the bottom of the greenstone belt, and possibly other features not yet identified. The proposed suture zones are also principle zones of structurally controlled gold mineralization, allowing for significant spin-off for understanding links between these sutures and Archean metallogenesis. The suture zones are also the focus of significant serpentinization that must have been the source of large-scale fluid flow and hydrogen production, both important ingredients for the emergence of primitive life and thereafter to sustain it to the present day.

The Makhonjwa Mountain treasure chest continues to yield unique observations with which to model how our planet transformed from a near molten ball to a plate tectonic driven recycling plant. There is always a ripple of excitement at scientific meetings whenever the lid of the Makhonjwa Mountain chest is pierced further open, ever so slightly. It is hoped that a deep geoscientific drillhole with associated science and technology related infrastructure will provide new scientific opportunities and also add significant value to the local communities.

\section{Acknowledgements}

Funding for the workshop was provided through the ICDP, the SA National Research Foundation (NRF), the Africa Earth Observatory Network (AEON), the bilateral South Africa-German program Inkaba yeAfrica project, and Travelport through Mr. Fred Daniel. These support structures are gratefully acknowledged. The MT work is financed through the GFZ, the DFG, and Inkaba yeAfrica program, and is led by Ute Weckmann and Oliver Ritter and their MT Group at Potsdam. The high-resolution aeromagnetic survey was conducted by Laurent Ameglio of GyroLAG and EXIGE (EXpertise In GEophysics), South Africa.

Nazla Hassen and UCT students are thanked for logistic support, and the staff at Travelport for their efficient and friendly hospitality, and for arranging transport to the potential drill site. I would in particular like to thank all participating scientists. This is AEON contribution number 94 .

\section{References}

Bédard, J.H., 2006. A catalytic delamination-driven model for coupled genesis of Archaean crust and sub-continental lithospheric mantle. Geochimica et Cosmochimica Acta, 70:1188-1214, doi:10.1016/j.gca.2005.11.008.

Biggin, A.J., de Wit, M.J., Langereis, C.G., Zegers, T.E., Voute, S., Dekkers, M.J., and Drost, K. 2011. Palaeomagnetism of Archaean rocks of the Onverwacht Group, Barberton Greenstone Belt (southern Africa): Evidence for a stable and potentially reversing geomagnetic field at ca. 3.5 Ga. Earth Planet. Sci. Lett., (2011), doi:10.1016/j.epsl.2010. 12.024 .

de Kock, M.O., Evans, D.A.D., and Beukes, N.J., 2009. Validating the existence of Vaalbara in the Neoarchean. Precambrian Res., 174(1-2):145-154.

de Wit, M.J and Ashwal, L.D., 1997. Greenstone belts: Oxford, U.K. (Oxford University Press).

de Wit, M.J., 2010. The deep-time treasure chest of the Makhonjwa Mountains. S. Afr. J. Sci., 106(5/6), Art. \#277, 2 pages, doi:10.4102/sajs.v106i5/6.277.

de Wit, M.J., Furnes, H., and Robins, B., 2011. Geology and tectonostratigraphy of the Onverwacht Suite, Barberton Greenstone Belt, South Africa. Precambrian Res., in press, doi:10.1016/j.precamres.2010.12.007.

Davies, G. F. (2007), Controls on density stratification in the early mantle, Geochem. Geophys. Geosyst., 8, Q04006, doi:10.1029/2006GC001414. 
Diener, J.F.A., Stevens, G., Kisters, A.F.M., and Poujol, M., 2005. Metamorphism and exhumation of the basal parts of the Barberton greenstone belt, South Africa: constraining the rates of Mesoarchaean tectonism. Precambrian Res., 143:87-112, doi:10.1016/j.precamres.2005.10.001.

Emmermann, R., and Lauterjung, J., 1997. The German Continental Deep Drilling Program KTB: overview and major results. J. Geophys. Res., 102:18179-18201.

Erzinger, J., and Stober, I., 2005. Long-term fluid production in the KTB pilot hole, Germany. Geofluids, Special Issue, 5:1-7, doi:10.1111/j.1468-8123.2004.00107.x.

Fliegel, D., Kosler, J., McLoughlin, N., Simonetti, A., de Wit, M.J., Wirth, R., and Furnes, H., 2010. In situ dating of the Earth's oldest trace fossil at 3.34 Ga. Earth Planet Sci. Lett., 299:290-298, doi:10.1016/j.epsl.2010.09.008.

Furnes, H., Banerjee, N.R., Muehlenbachs, K., Staudigel, H., and de Wit, M., 2004 Early life recorded in Archean pillow lavas. Science, 304:578-581, doi:10.1126/science.1095858.

Furnes, H., Rossing, M., Dillik, Y., and de Wit., M.J., 2009. Isua supracrustal belt (Greenland) - a vestige of a 3.8 Ga suprasubduction zone ophiolite, and the implications for Archean geology. Lithos, 113:115-132, doi:10.1016/j.lithos.2009. 03.043 .

Grove, T.L., and Parman, S.W., 2004. Thermal evolution of the Earth as recorded by komatiites. Earth Planet. Sci. Lett., 219:173-187.

Hamilton, W.B., 2007. Earth's first two billion years - the era of internally mobile crust. GSA Memoir, 200:233-296.

McLoughlin, N., Brasier, M.D., Wacey, D., Green, O.R., and Perry, R.S., 2007. On biogenicity criteria for endolithic microborings on early Earth and beyond. Astrobiology, 7(1):10-26, doi:10.1089/ast.2006.0122.

Moyen, J-F., Stevens, G., and Kirsters, A., 2006. Record of midArchean subduction from metamorphism in the Barberton terrain, South Africa. Nature, 422:559-562, doi:10.1038/ nature 04972 .

Nguuri, T.K., Gore, J., James, D.E., Webb, S.J. and the Kaapvaal Seismic Group, 2001. Crustal structure beneath southern Africa and its implications for the formation and evolution of the Kaapvaal and Zimbabwe cratons. Geophys. Res. Lett., 28:2501-2504, doi:10.1029/2000GL012587.

Schoene, B., and Bowring, S.A., 2010. Rates and mechanisms of Mesoarchean magmatic arc construction, eastern Kaapvaal craton, Swaziland. Geol. Soc. Am. Bull., 122(3/4):408-429, doi:10.1130/B26501.1.

Schoene, B., de Wit, M.J., and Bowring, S.A., 2008. Mesoarchean assembly and stabilization of the eastern Kaapvaal craton: a structural-thermochronological perspective. Tectonics, 27:TC5010, doi: 10.1029/2008TC002267.

Schoene, B., Dudas, F.O.L., Bowring, S.A., and de Wit, M.J., 2009. Sm-Nd isotopic mapping of lithospheric growth and stabilization in the eastern Kaapvaal craton. Terra Nova, 21:219228.doi:10.1111/j.1365-3121.2009.00877.x.

Strik, G.H.M.A., Blake, T.S., Zegers, T.E., White, S.H., and Langereis, C.G., 2003. Palaeomagnetism of flood basalts in the Pilbara Craton, Western Australia: late Archaean continental drift and the oldest known reversal of the geomagnetic field. $J$. Geophys. Res., 108:(B12), EPM 2-1-EPM 2-21.

Weckmann, U., Nube, A., Chen, X., Ritter, O., and de Wit, M. 2009. Overview and preliminary results of a magnetotelluric experiment across the southern Barberton greenstone belt. [11th SAGA Biennial Technical Meeting and Exhibition, Swaziland, 16-18 September], 583-586.

Van Kranendonk, M.J., 2007. Tectonics of early Earth. In Van Kranendonk, M.J., Smithies, R.H., and Bennet, V. (Eds.), Earth's Oldest Rocks. Developments in Precambrian Geology, 15: Amsterdam (Elsevier), 1105-1116.

\section{Author}

Maarten de Wit, Africa Earth Observatory Network, University of Cape Town, Rondebosch 7701, South Africa. e-mail: maarten.dewit@uct.ac.za.

\section{Figure Credits}

Fig. 1: Moctar Doucouré, AEON, University of Cape Town Fig. 3b, 3c: Dr. Ute Weckmann, GFZ-Potsdam, Germany 